\title{
HESFIRE: a global fire model to explore the role of anthropogenic and weather drivers
}

\author{
Y. Le Page ${ }^{1}$, D. Morton ${ }^{2}$, B. Bond-Lamberty ${ }^{1}$, J. M. C. Pereira ${ }^{3}$, and G. Hurtt ${ }^{4}$ \\ ${ }^{1}$ Pacific Northwest National Laboratory, Joint Global Change Research Institute, University of Maryland, \\ College Park, MD 20740, USA \\ ${ }^{2}$ NASA Goddard Space Flight Center, Greenbelt, MD 20771, USA \\ ${ }^{3}$ Centro de Estudos Florestais, Instituto Superior de Agronomia, Universidade de Lisboa, \\ Tapada da Ajuda, 1349-017 Lisbon, Portugal \\ ${ }^{4}$ Department of Geographical Sciences, University of Maryland, College Park, MD 20740, USA \\ Correspondence to: Y. Le Page (yannick.lepage@pnnl.gov)
}

Received: 23 May 2014 - Published in Biogeosciences Discuss.: 14 July 2014

Revised: 5 January 2015 - Accepted: 13 January 2015 - Published: 13 February 2015

\begin{abstract}
Vegetation fires are a major driver of ecosystem dynamics and greenhouse gas emissions. Anticipating potential changes in fire activity and their impacts relies first on a realistic model of fire activity (e.g., fire incidence and interannual variability) and second on a model accounting for fire impacts (e.g., mortality and emissions). In this paper, we focus on our understanding of fire activity and describe a new fire model, HESFIRE (Human-Earth System FIRE), which integrates the influence of weather, vegetation characteristics, and human activities on fires in a stand-alone framework. It was developed with a particular emphasis on allowing fires to spread over consecutive days given their major contribution to burned areas in many ecosystems. A subset of the model parameters was calibrated through an optimization procedure using observation data to enhance our knowledge of regional drivers of fire activity and improve the performance of the model on a global scale. Modeled fire activity showed reasonable agreement with observations of burned area, fire seasonality, and interannual variability in many regions, including for spatial and temporal domains not included in the optimization procedure. Significant discrepancies are investigated, most notably regarding fires in boreal regions and in xeric ecosystems and also fire size distribution. The sensitivity of fire activity to model parameters is analyzed to explore the dominance of specific drivers across regions and ecosystems. The characteristics of HESFIRE and the outcome of its evaluation provide insights into the influ-
\end{abstract}

ence of anthropogenic activities and weather, and their interactions, on fire activity.

\section{Introduction}

The human population has more than doubled in the past 50 years, expanding the scale and diversity of changes in the Earth system due to anthropogenic activity. The build-up of greenhouse gases in the atmosphere and the degradation and conversion of natural lands have major consequences for future climate, natural ecosystems, and human societies (Parry, 2007; Stocker et al., 2013). Interactions between human and natural systems are complex, yet observational data, field experiments, and various types of models continue to elucidate key linkages between climate variability, ecosystem function, and anthropogenic activities. This knowledge is essential for anticipating potential changes under future conditions and to design adaptation or mitigation strategies that promote the sustainability of the coupled human-Earth system.

One of these interactive processes linking human activities and natural ecosystems is fire (Bowman et al., 2009). Humans exert considerable influence over global fire activity (Le Page et al., 2010a); fire-driving deforestation accounts for an estimated $20 \%$ of the increase in atmospheric $\mathrm{CO}_{2}$ from human activities since preindustrial times (Bowman et al., 2011; van der Werf et al., 2010). Fire activity depends on a range of drivers covering three major components of the 
human-Earth system: the atmosphere (e.g., weather conditions), the terrestrial biosphere (e.g., fuel loads), and anthropogenic activities (e.g., land-use fires and fire suppression). The interaction among these drivers determines global fire activity, as illustrated in 1997-1998 when a strong El Niño occurrence led to extreme fire events around the world (Le Page et al., 2008), including unprecedented fires in peatlands and forests of Indonesia where human-caused fires emitted an estimated 13 to $40 \%$ of the world's annual fossil fuel emissions (Page et al., 2002).

Modeling fire activity under future climate, policy, and land use scenarios requires a framework with a broad range of variables (Pechony and Shindell, 2009) and a good understanding of the influence of these variables for model parameterization. Several global fire models have been developed in recent decades, each with a different focus (e.g., Arora and Boer, 2005; Li et al., 2013; Pfeiffer et al., 2013; Prentice et al., 2011; Thonicke et al., 2001, 2010). Among these examples, SPITFIRE (Thonicke et al., 2010) is a process-based fire model coupled to a vegetation model explicitly representing many physical properties of fire behavior, providing great capabilities regarding fire spread, fire intensity, and fire impacts (damage, mortality, emissions). The model developed by Li et al. (2013) has a particular emphasis on depicting anthropogenic ignitions, with good performances regarding global patterns of burned area.

One key prospect to build upon existing work, as mentioned by Thonicke et al. (2010), is to develop the capability for modeling fire spread over consecutive days. This capability has been reported in one global fire model focusing on pre-industrial era fires (Pfeiffer et al., 2013). In many ecosystems, multi-day fires are a major driver of the overall fire activity. In boreal regions, dry spells and heat waves in the days and weeks following ignition enable the growth of large fires (Abatzoglou and Kolden, 2011), and although those burning over 200 ha represent a minor fraction of all fires, they typically account for $90+\%$ of the total area burned (Stocks et al., 2002). In tropical forests, large-scale climate anomalies allow individual fires to spread over several weeks, including areas further away from the forest edge where ignitions typically occur (Morton et al., 2013). Similar findings have been reported for temperate regions, including in Mediterranean ecosystems (Pereira et al., 2005; Westerling et al., 2004). Modeling fire-climate interactions therefore requires careful attention to the duration of fire weather events.

Another opportunity for fire modeling research is model parameterization and their evaluation. Many early models had to extrapolate findings from local studies or to simplify key drivers of fire activity when information of some components was unavailable (e.g., ignitions independent of anthropogenic activities). Recently, model calibration has been applied to one (Thonicke et al., 2010) or a few (Li et al., 2013) parameters. Expanding this approach to additional parameters could yield relevant insights on fire drivers. Subsequent model evaluation is essential to assess our confidence in fire projections, especially regarding fire activity - the global spatiotemporal patterns of which are relatively well characterized by observation data (Mouillot et al., 2014) because depicting patterns of fire activity and their sensitivity to fire drivers is a pre-requisite to project realistic fire impacts. Evaluating fire models is challenging when they are embedded within vegetation models, however, because vegetation distribution strongly affects fire dynamics (Scott and Burgan, 2005), and if modeled inaccurately, this may lead to unrealistic fire projections for reasons unrelated to the fire parameterization.

This paper describes the development of the HESFIRE model (Human-Earth System FIRE), aimed at improving our understanding of current fire activity and our capacity to anticipate its evolution with future environmental and societal changes. HESFIRE is first developed as a stand-alone model, i.e., not integrated within a dynamic vegetation model. The major emphasis of this research is to outline the model structure and apply an optimization procedure to explore some of the research opportunities mentioned above. Our analysis has three main objectives: (1) explicit representation of fire ignition, spread, and termination, without exogenous constrain on fire duration; (2) consideration of atmospheric, terrestrial, and anthropogenic drivers in order to represent synergistic effects among weather, vegetation, and human activity-key steps towards the implementation of the fire model within human- and Earth-system models; and (3) model optimization and evaluation to improve our understanding of constraints on global fire activity and to quantify uncertainties of future fire activity projections.

\section{Methods}

\subsection{Model overview}

The structure of HESFIRE was designed to satisfy objectives 1 and 2 (representation of ignition, spread, and termination, and ease of integration to vegetation and integrated assessment models), and some of its parameters were optimized to estimate the quantitative role of poorly understood drivers and to maximize the agreement between modeled and observed fire regimes (objective 3 ). The model focuses on fires in natural ecosystems; deforestation and agricultural fires are dependent on very different dynamics (controlled spread, pile burning) and thus only considered as a source of ignition for escaped fires. The model is organized in three parts, with specific drivers for fire ignition, spread, and termination (Fig. 1):

- Fire ignition. Natural ignitions are a function of cloudto-ground lightning strikes and the probability of ignition per strike. Human ignitions reflect agricultural and ecosystem management as a function of land use density and national gross domestic product (GDP). 


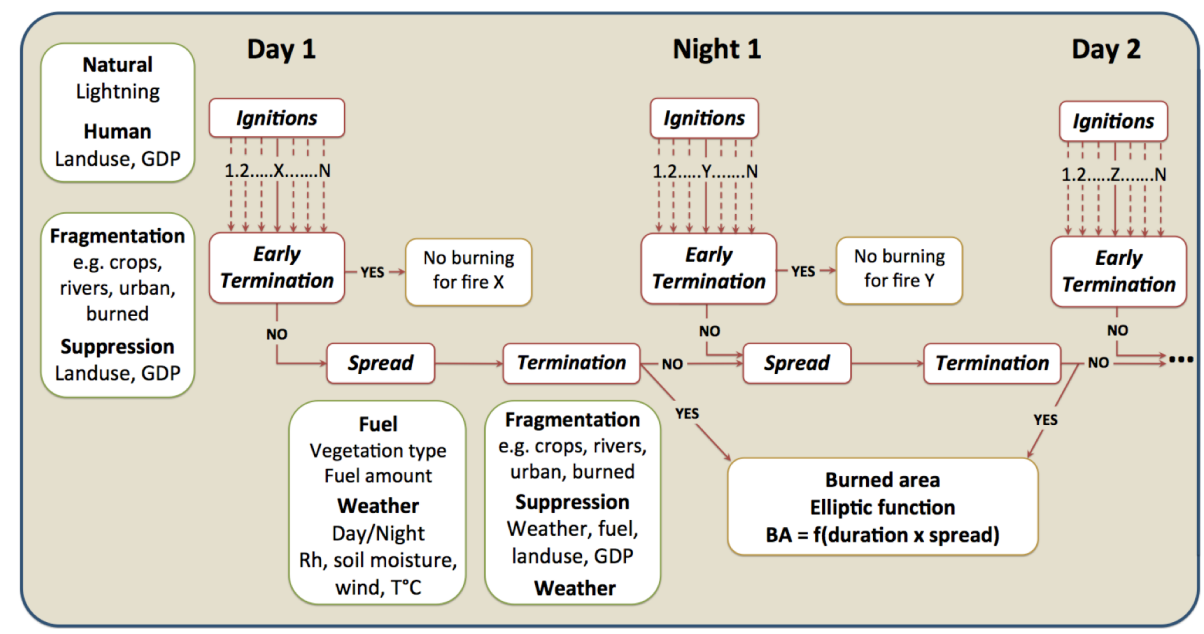

Figure 1. HESFIRE diagram.

- Fire spread. Fire spread rate is a function of weather conditions (relative humidity, temperature, wind speed), soil moisture, and fuel structure categories (forest, shrub, grass).

- Fire termination. Four factors control the termination of fires: weather conditions, fuel availability, landscape fragmentation, and fire suppression efforts (a function of land use, GDP, and fire suppressibility).

To account for the diurnal variability in fire spread and termination (see Introduction), every fire is tracked individually with a $12 \mathrm{~h}$ time step. The analyses presented in this paper were conducted with model runs at a resolution of $1^{\circ}$. HESFIRE is coded in Python 2.7 and is available at https://github.com/HESFIRE/HESFIRE1. The optimization procedure is included in the code.

\subsection{Model description}

The full list of parameters is described in Table 1. The following sections detail the fire ignition, spread, and termination modules.

\subsubsection{Fire ignitions}

Fires may occur due to natural ignitions ( $\left.\mathrm{NAT}_{\mathrm{ign}}\right)$ and human ignitions $\left(\mathrm{ANTHROP}_{\text {ign }}\right)$ :

$N_{\text {fires }}=\mathrm{NAT}_{\text {ign }}+$ ANTHROP $_{\text {ign }}$.

To introduce some of the stochasticity associated with fires, $N_{\text {fires }}$ represents the expected realization of a Bernoulli trial $(n=1000)$, and the final number of ignitions is computed following the actual trial.

\section{Natural ignitions}

Lightning strikes are the most frequent source of natural ignitions. Lightning ignitions are highly stochastic because of the localized occurrence of convective storms, variability in the frequency of cloud-to-ground lightning, and coincident rainfall which can terminate ignited fires before substantial spread occurs (see review in Podur et al., 2003). In HESFIRE, natural ignitions are the product of cloud-to-ground lightning strikes, the probability of ignition from a lightning strike, and the fractional cover of flammable vegetation in a given grid cell:

NATign $=\mathrm{CG}_{\text {flashes }} \cdot \mathrm{CG}_{\text {firep }} \cdot\left(1-\operatorname{Frag}_{\mathrm{n}}\right)$,

where $\mathrm{CG}_{\text {flashes }}$ is the number of cloud-to-ground lightning strikes, $\mathrm{CG}_{\text {ignp }}$ is the lightning ignition probability determined through the optimization procedure (see Sect. 2.3), and Frag $_{n}$ (fragmentation) is the fraction of the grid cell that cannot sustain a fire. Areas contributing to fragmentation include croplands, urban areas, water bodies, deserts, and areas burned within the last 8 months (the last definition included to avoid repeated burns within the same fire season).

\section{Anthropogenic ignitions}

Humans are the dominant source of fire ignition in most temperate and tropical ecosystems. Ignitions from human activities include fires for agriculture and ecosystem management, deforestation for agricultural expansion, accidental fires, and arson. Fire usage varies across countries, climate zones, and land use practices (Korontzi et al., 2006; Le Page et al., 2010a), and this diversity of human activity cannot be fully captured with current knowledge and data. However, wealth is an important driver of fire use in agricultural settings, since fire is typically the least costly tool to clear natural vegetation, control pests, or increase soil fertility (Laris, 2002; 
Table 1. Model parameters.

\begin{tabular}{|c|c|c|c|}
\hline Parameter & Description & Value and unit & $\begin{array}{l}\text { Source [optimization range], } \\
\text { if applicable }\end{array}$ \\
\hline \multicolumn{4}{|l|}{ Ignitions } \\
\hline $\mathrm{CG}_{\text {ignp }}$ & $\begin{array}{l}\text { Cloud-to-Ground ignition probability. Aver- } \\
\text { age probability of ignition from a cloud-to- } \\
\text { ground lightning strike on natural vegetation. }\end{array}$ & $6.8 \%$ & $\begin{array}{l}\text { Optimization } \\
{[2.8-16.6]}\end{array}$ \\
\hline ANTHROP $_{\text {ign }}$ & $\begin{array}{l}\text { Land Use ignitions. Original number of hu- } \\
\text { man ignitions per } \mathrm{km}^{2} \text { of land use per } 24 \mathrm{~h} \text {, } \\
\text { prior to applying density-decreasing func- } \\
\text { tion (see LUexp). }\end{array}$ & $2.3 \times 10^{-3} \mathrm{~km}^{-1}$ & $\begin{array}{l}\text { Optimization } \\
{[1.1-6] \times 10^{-3}}\end{array}$ \\
\hline $\mathrm{LU}_{\exp }$ & $\begin{array}{l}\text { Land Use exponent. Shape parameter: con- } \\
\text { trols the decreasing contribution of incre- } \\
\text { mental land use areas to human ignitions }\end{array}$ & 14.9 & $\begin{array}{l}\text { Optimization } \\
{[14.7-19.8]}\end{array}$ \\
\hline $\mathrm{GDP}_{\mathrm{exp}}^{\mathrm{a}}$ & $\begin{array}{l}\text { GDP exponent. Shape parameter: impact of } \\
\text { GDP on ignitions through land use practices. }\end{array}$ & 1.28 & $\begin{array}{l}\text { Optimization } \\
{[0.83-3.02]}\end{array}$ \\
\hline $\mathrm{LU}_{\text {thresh }}$ & $\begin{array}{l}\text { Land Use threshold. Fractional land use be- } \\
\text { yond which additional land use does not con- } \\
\text { tribute any more ignitions. }\end{array}$ & 0.1 & $\begin{array}{l}\text { Successive trials for reason- } \\
\text { able exponent value }{ }^{b}\end{array}$ \\
\hline $\mathrm{GDP}_{\text {range }}$ & $\begin{array}{l}\text { GDP range. Range of regional GDP control- } \\
\text { ling fire ignitions through land use practices. }\end{array}$ & $\begin{array}{l}\text { [USD 0-60 000] } \\
\text { cap }^{-1} \mathrm{yr}^{-1}\end{array}$ & Observed range $^{c}$ \\
\hline \multicolumn{4}{|l|}{ Spread } \\
\hline $\mathrm{BA}_{\text {frag }}$ & $\begin{array}{l}\text { Burned Area fragmentation. Delay before } \\
\text { burned areas can burn again (given sufficient } \\
\text { precipitation for fuel accumulation), mean- } \\
\text { while contributing to fragmentation. }\end{array}$ & 8 months & Model performance trials ${ }^{\mathrm{d}}$ \\
\hline Max $_{\text {forestrate }}$ & Maximum forest fire spread rate. & $0.28 \mathrm{~m} \mathrm{~s}^{-1}$ & (Scott and Burgan, 2005) \\
\hline Max $_{\text {shrubrate }}$ & Maximum shrublands fire spread rate. & $1.12 \mathrm{~m} \mathrm{~s}^{-1}$ & (Scott and Burgan, 2005) \\
\hline Max grassrate & Maximum grasslands fire spread rate. & $2.79 \mathrm{~m} \mathrm{~s}^{-1}$ & (Scott and Burgan, 2005) \\
\hline $\mathrm{RH}_{\text {range }}$ & $\begin{array}{l}\text { RH range. Range of relative humidity con- } \\
\text { trolling fire spread. }\end{array}$ & {$[30-80] \%$} & $\begin{array}{l}\text { (Li et al., 2012) } \\
\text { Scatterplot } \\
\text { Model performance trials }\end{array}$ \\
\hline $\mathrm{RH}_{\mathrm{exp}}$ & $\begin{array}{l}\text { RH exponent. Shape parameter: impact of } \\
\text { relative humidity on fire spread rate. }\end{array}$ & 1.18 & $\begin{array}{l}\text { Optimization } \\
{[0.52-1.31]}\end{array}$ \\
\hline $\mathrm{SW}_{\text {range }}$ & $\begin{array}{l}\text { Soil Water range. Range of volumetric soil } \\
\text { moisture controlling fire spread. }\end{array}$ & {$[20-35] \%$} & $\begin{array}{l}\text { Scatterplot } \\
\text { Model performance trials }\end{array}$ \\
\hline $\mathrm{SW}_{\exp }$ & $\begin{array}{l}\text { Soil Water exponent. Shape parameter: im- } \\
\text { pact of volumetric soil moisture on fire } \\
\text { spread rate. }\end{array}$ & 1.21 & $\begin{array}{l}\text { Optimization } \\
{[0.30-1.44]}\end{array}$ \\
\hline $\mathrm{T}_{\text {range }}$ & $\begin{array}{l}\text { Temperature range. Range of temperature } \\
\text { controlling fire spread. }\end{array}$ & {$[0-30]^{\circ} \mathrm{C}$} & $\begin{array}{l}\text { Scatterplot } \\
\text { Model performance trials }\end{array}$ \\
\hline $\mathrm{T}_{\exp }$ & $\begin{array}{l}\text { Temperature exponent. Shape parameter: } \\
\text { impact of air temperature on fire spread rate. }\end{array}$ & 1.78 & $\begin{array}{l}\text { Optimization } \\
{[0.8-3.8]}\end{array}$ \\
\hline
\end{tabular}


Table 1. Continued.

\begin{tabular}{|c|c|c|c|}
\hline Parameter & Description & Value and unit & $\begin{array}{l}\text { Source [optimization range], } \\
\text { if applicable }\end{array}$ \\
\hline \multicolumn{4}{|l|}{ Termination } \\
\hline Fuel $_{\text {range }}$ & $\begin{array}{l}\text { Fuel range. Range of precipitation con- } \\
\text { trolling termination probability through fuel } \\
\text { build-up. }\end{array}$ & {$[0.5-3] \mathrm{mm} \mathrm{day}^{-1}$} & $\begin{array}{l}\text { Scatterplot } \\
\text { Model performance trials }\end{array}$ \\
\hline Fuel $_{\text {span }}$ & $\begin{array}{l}\text { Fuel accumulation timespan. Timespan of } \\
\text { average precipitation controlling fuel build- } \\
\text { up. }\end{array}$ & 12 months & $\begin{array}{l}\text { (Greenville et al., 2009; van } \\
\text { der Werf et al., 2008; Van } \\
\text { Wilgen et al., 2004) } \\
\text { Model performance trials }\end{array}$ \\
\hline Fuel delay $_{\text {del }}$ & $\begin{array}{l}\text { Fuel accumulation delay. Delay from actual } \\
\text { precipitation to fuel build-up. }\end{array}$ & 3 months & Model performance trials \\
\hline Fuel $_{\exp }$ & $\begin{array}{l}\text { Fuel exponent. Shape parameter: impact of } \\
\text { precipitation over }-15 \text { to }-3 \text { months on fire } \\
\text { termination probability, a proxy fuel build- } \\
\text { up. }\end{array}$ & 1.72 & $\begin{array}{l}\text { Optimization } \\
{[1.62-3.65]}\end{array}$ \\
\hline Frag & $\begin{array}{l}\text { Fragmentation range. Range of fractional } \\
\text { landscape fragmentation controlling termi- } \\
\text { nation probability. }\end{array}$ & {$[0-1]$} & Observed range \\
\hline Frag $_{\exp }$ & $\begin{array}{l}\text { Fragmentation exponent. Shape parameter: } \\
\text { impact of landscape fragmentation on fire } \\
\text { termination probability. }\end{array}$ & 1.81 & $\begin{array}{l}\text { Optimization } \\
{[0.94-2.48]}\end{array}$ \\
\hline $\mathrm{LU}_{\text {range }}$ & $\begin{array}{l}\text { Land Use range. Range of fractional } \\
\text { land use controlling termination probability } \\
\text { through suppression efforts. }\end{array}$ & {$[0-0.1]$} & $\begin{array}{l}\text { Successive trials for reason- } \\
\text { able exponent value }\end{array}$ \\
\hline LUSUP $_{\exp }$ & $\begin{array}{l}\text { Land Use SUPpression exponent. Shape pa- } \\
\text { rameter: impact of land use on fire termina- } \\
\text { tion probability through suppression efforts, } \\
\text { in interaction with GDP (below). }\end{array}$ & 4.08 & $\begin{array}{l}\text { Optimization } \\
{[1.62-7.18]}\end{array}$ \\
\hline GDP $_{\text {range }}$ & $\begin{array}{l}\text { GDP range. Range of regional GDP control- } \\
\text { ling fire suppression effort. }\end{array}$ & $\begin{array}{l}\text { [USD 0-60000] } \\
\text { cap }^{-1} \mathrm{yr}^{-1}\end{array}$ & Observed range \\
\hline $\mathrm{GDP}_{\mathrm{exp}}^{\mathrm{a}}$ & $\begin{array}{l}\text { GDP exponent. Shape parameter: impact of } \\
\text { GDP on suppression effort through land use } \\
\text { practices. }\end{array}$ & 1.28 & $\begin{array}{l}\text { Optimization } \\
{[0.83-3.02]}\end{array}$ \\
\hline
\end{tabular}

\footnotetext{
a: In order to limit the number of parameters to optimize for the first version of the fire model, GDP $_{\text {exp }}$ is attributed the same optimized value when applied to either fire ignitions or fire termination.

$\mathrm{b}$ : Successive trials for reasonable exponent value. This was applied to the range of land use fraction for ignition and suppression (see Sect. 2.2.1.2). $c^{c}$ : Observed range. The range covers all or most of the values across the world. For GDPrange, a few grid cells are beyond the USD 60000 per capita upper limit (in Qatar).

$\mathrm{d}$ : Model performance trials. These parameters were not determined using the full optimization procedure, but we tried a limited number of values (e.g., 5,8 , and 12 months for $\mathrm{BA}_{\text {frag }}$ ) and selected the one leading to the best fit.

e: Scatterplot. We used scatterplot to determine the range of influence of some drivers, namely RH, soil moisture, temperature and the precipitation fuel proxy. An example is given in Fig. S2 in the Supplement.
}

Thrupp et al., 1997). Thus we represent anthropogenic ignitions as a function of land use intensity and national GDP, where higher fractional land use and lower GDP increase anthropogenic fire ignitions. Similar to the approach used in the SPITFIRE model (Thonicke et al., 2010), we assume that initial settlements bring more ignitions relative to additional ones:

$\mathrm{ANTHROP}_{\text {ign }}=\left(1-\mathrm{GDP}_{\mathrm{n}}\right)^{\mathrm{GDP}_{\exp }} \cdot \mathrm{LU}_{\text {ign }} \cdot \int_{\mathrm{LU}=0}^{\mathrm{LU}=\mathrm{LU}_{\text {tot }}}$
$\left(\frac{\left(\mathrm{LU}_{\text {thresh }} \cdot \text { cell_area }\right)-\min [\mathrm{LU},(\mathrm{LU} \text { thresh } \cdot \text { cell_area })]}{\left(\mathrm{LU}_{\mathrm{thresh}} \cdot \text { cell_area }\right)}\right)^{\mathrm{LU}_{\text {exp }}}$,

where $\mathrm{GDP}_{\mathrm{n}}$ is the normalized gross domestic product per capita (from USD 0 to 60000 ), GDP exp $_{\text {the associated shape }}$ parameter, $\mathrm{LU}_{\mathrm{ign}}$ the initial number of ignitions per $\mathrm{km}^{2}$ of land use, $\mathrm{LU}_{\text {tot }}$ the land use area $\left(\mathrm{km}^{2}\right)$ in the grid cell considered, computed as the sum of crops and urban areas (see Sect. 2.4.3.), cell_area the area of the grid cell $\left(\mathrm{km}^{2}\right.$, a function of latitude), $\mathrm{LU}_{\text {thresh }}$ the fractional land use value beyond which additional land use does not contribute any more ignitions, and $\mathrm{LU}_{\text {exp }}$ the shape parameter controlling the decrease in the amount of additional ignitions with incremental land 
use. $L_{\text {thresh }}$ was initially set to 1 , but the exponent parameter $\mathrm{LU}_{\exp }$ was systematically optimized at very high values. $\mathrm{LU}_{\text {thresh }}$ was thus progressively decreased to a final value of 0.1 , pointing to a rapid saturation of human ignitions with land use. $\mathrm{LU}_{\text {ign }}$ and $\mathrm{GDP}_{\exp }$ were also determined through the optimization procedure. Equation (3) conveys the following fire-driving mechanisms:

- Anthropogenic ignitions increase with human occupation of the landscape, but at a lower rate with additional land use, and saturate once $10 \%$ of the landscape is occupied (Fig. S1 in the Supplement).

- Fire use for land use management depends on the regional GDP, with maximum fire use in the poorest regions, and virtually no fire use at all for regions beyond USD 60000 per capita. Only one country (Qatar) has a GDP beyond this range in the data. In the future, more countries are expected to have a GDP over USD 60000 per capita, and thus would not have any human ignitions (see discussion).

\subsubsection{Fire spread}

The rate of fire spread $F_{\text {rate }}$ is modeled for three broad vegetation types - forest, shrub, and grass - and varies as a function of their respective maximum fire spread rate, of relative humidity, soil moisture, temperature, wind speed, and fuel structure:

$F_{\text {rate }}=\operatorname{Max}_{\text {rate }} \cdot\left(1-\mathrm{RH}_{\mathrm{n}}^{\mathrm{RH}_{\text {exp }}}\right) \cdot\left(1-\mathrm{SW}_{\mathrm{n}}^{\mathrm{SW}_{\exp }}\right) \cdot\left(1-T_{\mathrm{n}}^{T_{\mathrm{exp}}}\right) \cdot G(W)$

$\mathrm{RH}_{n}, \mathrm{SW}_{\mathrm{n}}$ and $T_{\mathrm{n}}$ representing the normalized $\mathrm{RH}, \mathrm{SW}$ and $T$, i.e.:

$\mathrm{RH}_{\mathrm{n}}=\max \left[\min \left[\frac{\mathrm{RH}-\mathrm{RH}_{\text {range[1] }}}{\mathrm{RH}_{\text {range[2] }}-\mathrm{RH}_{\text {range[1] }}} 1\right], 0\right]$

where $\mathrm{Max}_{\text {rate }}$ is the maximum fire spread rate, constrained by observations (Scott and Burgan, 2005): $0.28 \mathrm{~ms}^{-1}$ in forests, $1.12 \mathrm{~m} \mathrm{~s}^{-1}$ in shrubs, and $2.79 \mathrm{~m} \mathrm{~s}^{-1}$ in grasses. $\mathrm{RH}_{\mathrm{n}}$ is the normalized relative humidity, from $\mathrm{RH}_{\text {range[1] }}=30 \%$ to $\mathrm{RH}_{\text {range[2] }}=80 \%$ (adapted from Li et al., 2012). $\mathrm{SW}_{\mathrm{n}}$ and $T_{\mathrm{n}}$ are the normalized $0-10 \mathrm{~cm}$ layer soil moisture $(20-35 \%$, used as a proxy for fuel moisture) and temperature $\left(0-30{ }^{\circ} \mathrm{C}\right)$, as determined by simple data analysis and parameter value trials (see Table 1). $\mathrm{RH}_{\mathrm{exp}}, \mathrm{SW}_{\mathrm{exp}}$, and $T_{\exp }$ are the optimized shape parameters controlling the fire-driving relationship. Fires are modeled with an elliptical shape, with higher winds leading to higher fire spread rate and to more elongated fires. The influence of wind, $G(W)$, is computed following the method adapted from Arora and Boer (2005) described in Li et al. (2012), as a function of the length-to-breadth (LB) and head-to-back $(\mathrm{HB})$ ratios of the elliptical fire, both of which depend on wind speed $(w)$.

$$
\begin{aligned}
& \mathrm{LB}=1+10 \cdot\left(1-e^{-0.06 \cdot \omega}\right) \\
& \mathrm{HB}=\mathrm{LB}+\frac{\mathrm{LB}+\left(\mathrm{LB}^{2}-1\right)^{0.5}}{\mathrm{LB}-\left(\mathrm{LB}^{2}-1\right)^{0.5}} \\
& G(W)=2 \cdot \frac{\mathrm{LB}}{(1+1 / \mathrm{HB})} \cdot 0.0455
\end{aligned}
$$

Within a grid cell, fires are assumed to spread with equal probability to each of the three vegetation types. Their respective burned area therefore reflects their specific fire spread rates and fraction within the grid cell. Given the large size of the model grid cells $\left(1^{\circ} \times 1^{\circ}\right)$, fire spread to neighboring grid cells is not considered.

\subsubsection{Termination}

Individual, multi-day fires are modeled from ignition to termination. Fire termination may occur in four ways: weather conditions are no longer favorable to fire spread, the fire is stopped by landscape fragmentation, by lack of fuel, or suppressed by fire-fighting activities. Each termination pathway contributes to the overall probability of termination; fire termination is then determined by the same Bernoulli trial stochastic approach applied to fire ignitions. Fire termination is computed every $12 \mathrm{~h}$ and may occur before any spread (i.e., right after ignition).

$N$ fires $_{t+1}=N$ fires $_{t} \cdot\left\{\begin{array}{l}\left(1-\text { Fuel }_{\text {termp }}\right) \cdot\left(1-\text { Frag }_{\text {termp }}\right) \cdot \\ \left(1-\text { Supp }_{\text {termp }}\right) \cdot\left(1-\text { Weather }_{\text {termp }}\right)\end{array}\right\}$,

where $N_{\text {fires }}$ is the number of active fires, and Fuel termp, $_{\text {, }}$

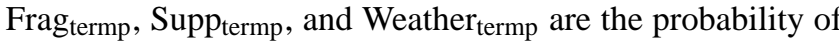
termination due to each factor.

Weather-related termination occurs when fire spread rate decreases to zero, that is when $\mathrm{RH}$ is $80 \%$ or above, soil moisture is $35 \%$ or above, or when the temperature drops below freezing (see Sect. 2.2.2).

If $\mathrm{RH} \geq \mathrm{RH}_{\max }$ or $\mathrm{SW} \geq \mathrm{SW}_{\max }$ or $T \leq T_{\min }$

Weather termp $=1$

Else Weather termp $=0$

Fuel load and its impact on termination is a function of the cumulative precipitation prior to the current time step, as an indicator of water limitation on fuel build-up in arid areas:

Fuel $_{\text {termp }}=1-$ Precip $_{\mathrm{n}}^{\text {Fuel }_{\text {exp }}}$,

where Precip $_{\mathrm{n}}$ is the average precipitation from -15 to -3 months, normalized from $0.5 \mathrm{~mm} \mathrm{day}^{-1}\left(\right.$ Precip $\left._{\mathrm{n}}=1\right)$ to $3 \mathrm{~mm} \mathrm{day}^{-1}\left(\right.$ Precip $\left._{\mathrm{n}}=0\right)$. The averaging window was determined based on values from the literature (Greenville et al., 2009; van der Werf et al., 2008; Van Wilgen et al., 2004), 
which consider a 12-month to 24-month window, and adjusted through model performance assessment with different values. The normalization range was determined based on simple data analysis and parameter value trials (see Table 1 and Fig. S2). Fuel exp $_{\text {is }}$ the shape parameter, determined through the optimization procedure.

The influence of landscape fragmentation is computed as

Frag $_{\text {termp }}=$ Frag $_{\mathrm{n}}^{\text {Frag }_{\text {exp }}}$,

where Frag $_{\mathrm{n}}$ is the fraction of the grid cell that cannot sustain a fire. Areas that cannot sustain natural vegetation fires include croplands, urban areas, water bodies, and deserts. Because HESFIRE does not explicitly represent fuel loads, areas that burned up to 8 months prior to the day being considered also contribute to fragmentation, to avoid repeated burns within the same fire season, but allowing fires in the following fire season if enough precipitation occurs (e.g., in subSaharan Africa). Fragexp is the shape parameter, determined through the optimization procedure. Note that this is a simple fragmentation index; more advanced approaches can include aspects of connectivity, edge density, and more (Jaeger, 2000; Schumaker, 1996).

Fire suppression is modeled as a function of land use (human presence), GDP, and fire suppressibility. This approach assumes that (1) fire suppression activities are limited in regions with low GDP, and in remote areas with little land use regardless of GDP (e.g., boreal fires in Canada and Alaska, bush fires in northern Australia); and (2) the more fire prone the conditions (weather, fuel), the less effective fire suppression efforts are. These assumptions are embodied in the following equation:

$\operatorname{Supp}_{\text {termp }}=\left(1-\left(1-\right.\right.$ LU $\left.\left._{\mathrm{n}}^{\mathrm{LUSUPexp}}\right) \cdot\left(1-\mathrm{GDP}_{\mathrm{n}}^{\mathrm{GDPexp}}\right)\right)$

$\cdot\left(1-F_{\text {suppressibility }}\right)$,

where $L U_{n}$ is the fraction of the grid cell with land use, normalized from $0\left(\mathrm{LU}_{\mathrm{n}}=0\right)$ to $0.1\left(\mathrm{LU}_{\mathrm{n}}=1\right)$, LUSUP $\mathrm{exp}$ is a shape parameter controlling the increase in suppression efforts with land use density, $\mathrm{GDP}_{\mathrm{n}}$ is the normalized GDP (from USD 0 to 60000 per capita), $\mathrm{GDP}_{\exp }$ is the shape parameter, and $F_{\text {suppressibility is a proxy for the influence }}$ of weather and fuel on easiness of suppression. LUSUP $P_{\exp }$

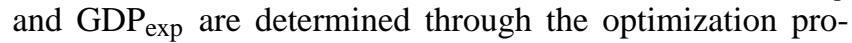
cedure. Note that GDP $_{\exp }$ has the same value as in Eq. (3) for human ignitions. GDP has a negative relationship to fires through both ignitions and suppression, leading to an underconstrained optimization if maintaining two separate parameters. $F_{\text {suppressibility is dependent on weather conditions and }}$ fuel, assuming lower suppressibility with windier, drier, and hotter conditions and with higher fuel load:

$$
\begin{aligned}
& F_{\text {suppressibility }}=\left(1-\mathrm{RH}_{\mathrm{n}}^{\mathrm{RH}_{\exp }}\right) \cdot\left(1-\mathrm{SW}_{\mathrm{n}}^{\mathrm{SW}_{\exp }}\right) \\
& \cdot\left(1-T_{\mathrm{n}}^{T_{\exp }}\right) \cdot G(W) \cdot \text { Precip }_{\mathrm{n}}^{\mathrm{FUELexp}} .
\end{aligned}
$$

Previous studies on the influence of climate conditions on fire intensity and suppressibility are limited and have mostly focused on process-based modeling (Rothermel and Forest, 1972; Thonicke et al., 2010). Our approach is thus a simple combination of the fuel and weather variables that have an impact on fire suppression until more research is done on the subject.

\subsection{Model optimization}

The nine optimized parameters (Table 1) are classified into two categories:

a. Non-shape parameters (two out of nine) account for quantitative impacts of fire drivers: the default number of human ignitions per land use area $\left(\mathrm{LU}_{\mathrm{ign}}\right)$ and the probability that lightning strikes on vegetated areas ignite a fire $\left(\mathrm{CG}_{\text {ignp }}\right)$.

b. Shape parameters (seven out of nine) control the shape of the relationship between a given driver and fire. For example, relative humidity is assumed to limit fire spread between 30 and $80 \%$, but the linear or nonlinear relationship with relative humidity between 30 and $80 \%$ and fire spread is unclear. To optimize this type of parameter, the variable was first normalized between 0 $\left(\mathrm{RH}_{\text {range[1] }}=30 \%\right)$ and $1\left(\mathrm{RH}_{\text {range[2] }}=80 \%\right)$. Then the actual impact of $\mathrm{RH}$ on fire spread rates was computed with a shape parameter, $\mathrm{RH}_{\text {exp }}$ (Eq. 4).

These shape parameters can convey a wide range of potential driving relationships (Fig. 2). The exponential function was selected to balance gains in process understanding and costs associated with computational efforts. We acknowledge that complex fire-driving relationships (e.g., sigmoid) cannot be accounted for here. Exploring such aspects would require two or more parameters per driver, which would lead to computational speed and convergence problems during optimization. The objective was to infer general conclusions on otherwise little-understood fire drivers, for which singleparameter functions were well adapted.

We used a Markov chain Monte Carlo approach based on the Metropolis algorithm (Metropolis et al., 1953) to obtain best-fit parameter values. The algorithm generates trial sets of parameters pseudo-randomly, and compares model outputs with observation data. Each trial set is either accepted or rejected, and the history of acceptance and rejection guides the generation of subsequent trial sets. Acceptance occurs if a trial set leads to a better fit than the current parameterization. To limit the risk of convergence to local optimums, acceptance may also occur if the trial set does not have a better 


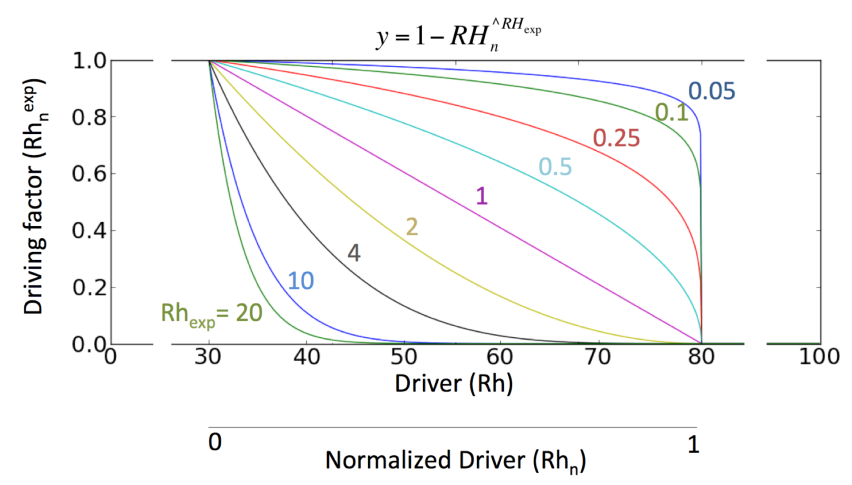

Figure 2. Control of shape parameters (exponents, here $\mathrm{RH}_{\exp }$ ) on fire-driving relationships. The exponent can take any value (from 0.033 to 30 ) as determined by the optimization procedure, thus covering a wide space of potential fire-driving influence.

fit, with decreasing likelihood as the difference with the best fit increases. Upon acceptance (rejection), the range of possible parameter values is increased (decreased) before the next trial set is generated. The algorithm typically explored hundreds to over a thousand sets of trial parameter values before converging to a best fit (Fig. 3).

The optimization metric was defined to minimize classification error across seven classes of annual burned fraction (interval boundaries: $0,1,5,10,20,35,50+\%$ of the grid cell), and to maximize the correlation with observed interannual variability. Within each class, grid cells are attributed continuous values based on linear interpolation: a grid cell with $3 \%$ burned fraction is given the value of 2.5 , being in the middle of the second interval boundaries. This classification approach aims at capturing important changes that would have little weight on the optimization if using direct burned fraction value. In the context of ecosystem sustainability and fire impacts in general, a difference between 3 and $4 \%$ in fire-sensitive tropical forests is more relevant to capture than between 33 and $34 \%$ in fire-adapted grasslands of northern Australia.

$$
\begin{aligned}
& \mathrm{Opt}_{\text {index }}= \\
& \frac{\sum_{\text {gridcell }=1}^{n}\left(\mathrm{MOD}_{\text {fclass }}-\mathrm{OBS}_{\text {class }}\right)^{2}+\sum_{\text {gridcell }=1}^{n}\left(1-\mathrm{IAV}_{\text {correcoef }}(\mathrm{Mod}, \mathrm{OBS})\right)}{n}
\end{aligned}
$$

where $\mathrm{MOD}_{\text {fclass }}$ and $\mathrm{OBS}_{\text {class }}$ are the modeled and observed fire classification, and $\mathrm{IAV}_{\text {correcoef }}$ the correlation coefficients for both time series, for each grid cell.

The optimization was performed using modeled and observed burned area over 5 years (2002-2007). Fewer than $2 \%$ of all land grid cells were used for the optimization step; these were selected manually to represent the broad spectrum of fire regimes and the range of environmental conditions around the world (e.g., biomes, land use density, fuel gradient in semi-arid regions, GDP, see Figs. S3 and S4 in the Supplement). No grid cells were selected from South America,

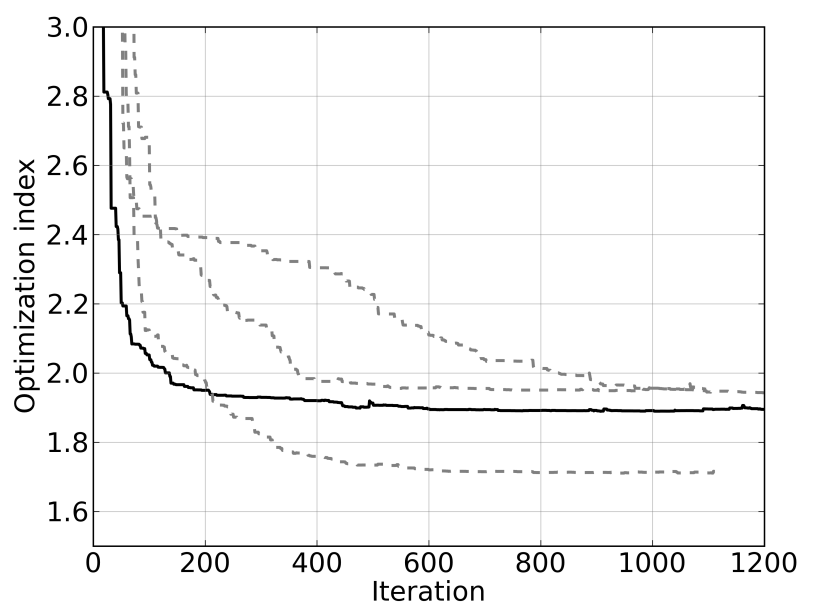

Figure 3. HESFIRE's performance through the optimization procedure iterations. The solid line represents the optimization of the final model. The dashed lines represent the optimization of three of the alternative runs, using different sets of grid cells and years to evaluate the robustness of the parameters.

in order to test the model's ability to reproduce fire patterns under combinations of drivers it might not have encountered during optimization (e.g., Brazil's GDP is higher than other tropical countries in Africa and Southeast Asia), and under specific conditions that cannot be fully depicted by the model drivers (e.g., fire practices). To evaluate the robustness of the algorithm convergence, we performed 20 optimization runs, each using different grid cells and years.

\subsection{Model evaluation}

We evaluated HESFIRE using satellite-derived estimates of (1) burned area and aggregate characteristics of regional fire activity over 1997-2010 (fire incidence, seasonality, interannual variability); and (2) the regional distribution of fire size for the year 2005 .

Finally, we performed a sensitivity analysis to evaluate the influence of each model parameter on the averaged annual burned area within the model. For each parameter, the model was run twice, with the parameter changed to +50 and $-50 \%$ of its original value while everything else was kept the same. For each grid cell, we then extracted the parameter that generated the largest change in burned area. This approach has been applied in numerous modeling studies (e.g., Potter et al., 2001; White et al., 2000; Zaehle and Friend, 2010); see Saltelli et al. (2000) for alternatives methods. Results of the sensitivity analysis were grouped into four classes to map the spatial distribution of parameter sensitivity: (1) weather (lightning strikes, RH, soil moisture, and temperature parameters); (2) fuel (precipitation proxy); (3) anthropogenic (ignitions and suppression parameters); (4) fragmentation (landscape fragmentation parameter). 


\subsection{Data}

\subsubsection{Weather}

We combined two data sources to estimate the spatial and temporal variability in natural ignitions from lightning. The timing and location of cloud-to-ground lightning strikes is based on convective precipitation (Allen and Pickering, 2002) using sub-daily convective precipitation data from NCEP (see below). We then corrected biases in the spatial distribution of lightning strikes identified by the authors of this method with the observed Lightning Imaging Sensor/Optical Transient Detector (LIS/OTD) climatology (Christian et al., 2003), converted to cloud-to-ground lightning strikes following Prentice and Mackerras (1977).

Sub-daily relative humidity, soil moisture, temperature, wind speed, and convective precipitation data were obtained from the NCEP-DOE Reanalysis II project (Kanamitsu et al., 2002). For fuel limitation, we used monthly precipitation data from the Global Precipitation Climatology Project (GPCP, Adler et al., 2003). All data were interpolated linearly from their original resolution $\left(2.5^{\circ}\right.$ for NCEP) to the model $1^{\circ}$ resolution, and averaged from 6-hourly to 12 hourly.

\subsubsection{Land cover}

We used the GlobCover version 2.3 land cover map (Bontemps et al., 2011) to estimate the distribution of natural ecosystems and anthropogenic land use at $1^{\circ}$ resolution. GlobCover data were re-gridded from the original $300 \mathrm{~m}$ resolution to $1^{\circ}$ and reclassified from 22 land cover classes to the five classes used in the model (forests, shrublands, grasslands, croplands/urban, bare areas/water).

\subsubsection{Land use and GDP}

Land use area was computed as the sum of crops and urban lands in the GlobCover data. National GDP was inferred from the 2009 World Factbook (CIA, 2009).

\subsubsection{Fire activity}

The Global Fire Emission Database (GFED version 3, van der Werf et al., 2010) was used in the optimization procedure as well as to evaluate the representation of fire incidence, seasonality, and interannual variability in HESFIRE. The regional distribution of fire was evaluated with observations from the MODIS MCD45 burned area product (Roy et al., 2008). Note that both of these products feature substantial uncertainties (Giglio et al., 2010, 2013; Roy et al., 2008). In the case of burned area from GFED, we consider uncertainties to be roughly $25-50 \%$ based on these papers and on a comparison of GFED versions 2, 3, and 4 .

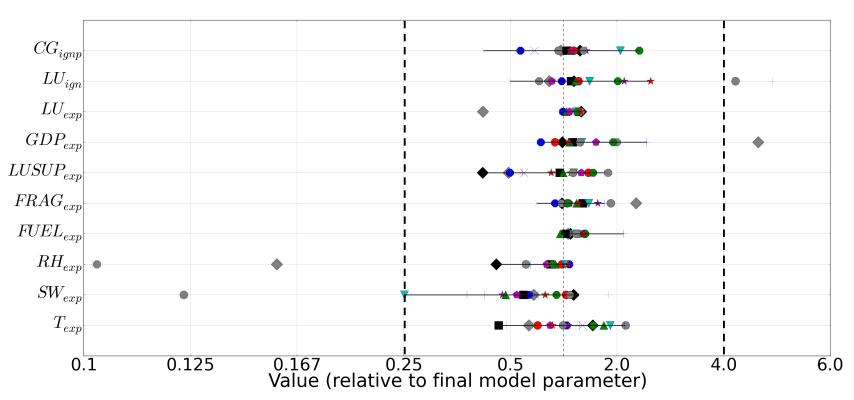

Figure 4. Parameter variability across the set of optimization runs with different grid cells and years. Among the 20 runs, 16 reached a relatively consistent parameterization (see text). These are represented as colored markers and their range is shown by the black lines. For the other four runs, parameters are shown as grey markers. The vertical dashed lines indicate the lower and upper (symmetric) thresholds of parameters range which were used to separate these four runs.

\section{Results}

\subsection{Optimization}

The parameters inferred by the optimization procedure are consistent with our current understanding of fire drivers, and provide a quantitative estimate on otherwise poorly constrained relationships. Their value, variability across the 20 optimization runs and implications for fire ignition, spread, and termination are presented in Figs. 4 and 5. In 16 out of the 20 optimization runs performed, the final set of parameters was relatively similar to the final model, and changes in parameter values were mostly compensative of each other, especially for correlated fire drivers (e.g., relative humidity and soil moisture). In four cases, the optimization procedure reached an alternative configuration, with one or several parameters differing from the final parameterization by a factor greater than five, and were discarded as unsuccessful parameterizations, most likely stuck at local optimums. Hereafter, we will refer to the remaining 16 models to consider parameter uncertainty, represented by the black lines in Fig. 4 and shaded areas in Fig. 5.

For fire ignitions, the probability that lightning strikes on natural vegetation ignite a fire under fire prone conditions is optimized at $6.8 \%$ (uncertainty range [2.8 to $16.6 \%$ ]), comparable to the value inferred from the literature used in SPITFIRE (4\%, Thonicke et al., 2010). We emphasize, however, that this metric is a general probability which does not depict the complex relationship between cloud-to-ground lightning strikes and fire ignitions (Podur et al., 2003). Regarding anthropogenic sources, the optimization procedure suggests that the number of human ignitions saturates at a low landuse fraction, with any additional land use beyond 2-3\% of the grid cell area having no contribution to ignitions (Fig. 5a). The final number of anthropogenic ignitions further depends on GDP per capita, with a nearly linear relationship (Fig. 5b). 

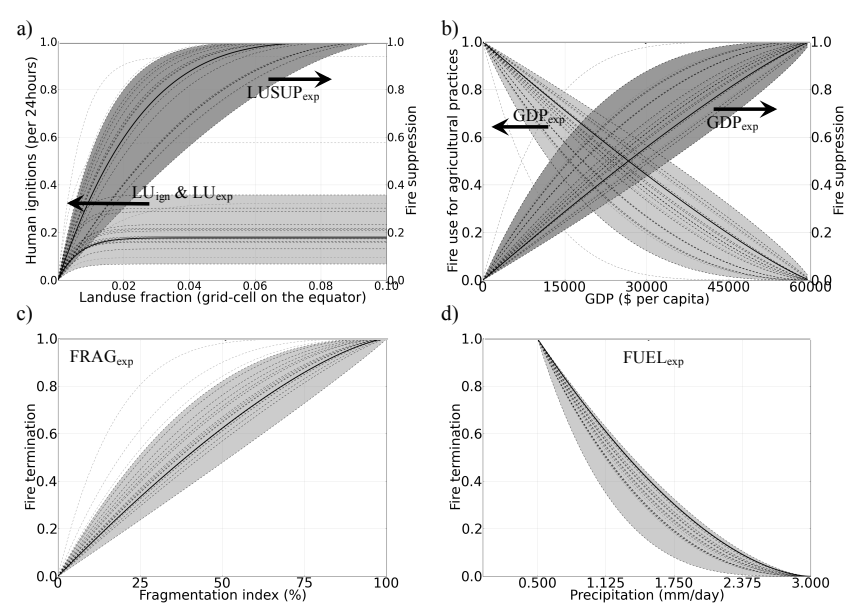

Figure 5. Optimized model parameters and their influence on fire ecology. For each plot, the parameter(s) contributing to the shape of the function are indicated, and the thick black line represents the parameter influence in the final model. The dotted black lines represent the 16 optimization runs that reached a similar parameterization to the final model, the shaded area showing the range of their influence. The dotted grey lines represent the four optimization runs which reached a parameterization substantially different from the final model (see text).

Regarding fire spread, exponents depicting the role of $\mathrm{RH}$ and soil moisture indicate relatively linear relationships, with significant uncertainty (RHexp $=1.18$ [0.52 to 1.29]; SWexp $=1.21$ [0.3 to 1.44$]$ ) (Fig. 5d, e). The relationship with temperature is slightly nonlinear $(\operatorname{Texp}=1.78[0.80$ to 3.30]), indicating a lower impact of temperature changes towards the higher range of the influence interval $\left(\left[0-30^{\circ} \mathrm{C}\right]\right)$. Optimizing the model without the influence of temperature produced relatively similar performances, except in highlatitude regions where temperature constraints encompass limits on fire spread (e.g., snow cover).

For fire termination, the anthropogenic influence indicated a rapid saturation of suppression efforts with land use density (LUSUPexp $=4.08$ [1.62 to 7.18]) and maximum suppression at 0.1 fractional land use (Fig. 5a). The influence of GDP was approximately linear $($ GDPexp $=1.28[0.97$ to 2.24$]$ ), while the influence of landscape fragmentation was slightly nonlinear (FRAGexp $=1.41$ [0.83 to 3.02]). The cumulative precipitation proxy for fuel load also indicated a slightly nonlinear relationship (FUELexp $=1.72$ [1.62 to 3.65]). Climatic factors only operate through condition thresholds (e.g., relative humidity over $80 \%$ ) and were thus not optimized.

\subsection{Global 1997-2010 run and comparison to observation-derived data}

The modeled and observed average annual burned fractions across the world are illustrated in Fig. 6. In South America, which was not part of the optimization phase, HESFIRE depicts most spatial patterns as well as the actual incidence
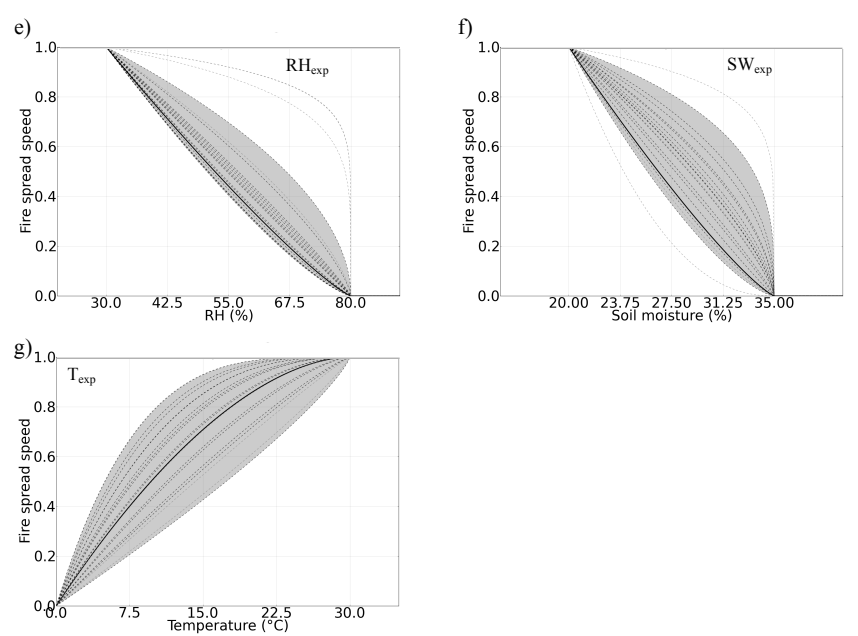

Figure 5. Continued.

of fires, including increased fire activity associated with the expansion of human activities into the Amazon basin, the competing influence of the moisture gradient (Le Page et al., $2010 \mathrm{~b}$ ), and fires associated with pastures and grasslands in northern Venezuela and southern Columbia. In Africa and Australia, HESFIRE generally captures high fire incidence in grassland areas, although modeled spatial patterns in Africa are more uniform than observations (probably due to the simple representation of fuel, see Sect. 4.1.2). HESFIRE also reproduces areas of moderate fire incidence in Southeast Asia, Kazakhstan and southwestern Europe, and identifies strong fire gradients with decreasing fuel load across semiarid and arid regions (e.g., in Africa, central Australia), although with some limitation especially at the northern edge of sub-Saharan Africa where fire incidence is overestimated. Conversely, HESFIRE performs poorly in several regions, including the pan-boreal region, at least partly due to a bias in the climate and soil moisture data (see discussion), as well as Central America, Mexico, the horn of Africa, and some areas of the Middle East where fire incidence is overestimated. It also underestimates fire incidence in Indonesia, where soil moisture remains beyond the fire prone threshold almost all year long. Fires preferentially occur on areas with degraded forests and drained peatlands in Indonesia (Page et al., 2002; van der Werf et al., 2008), where moisture dynamics is not captured with a $2.5^{\circ}$ resolution data set.

Aggregated monthly burned area across 14 regions (Fig. 7) and their respective fire size distribution are illustrated in Fig. 8. The monthly time series provide insights into the performance of HESFIRE on regional fire incidence, fire seasonality, and interannual variability. Average burned area in the main fire incidence regions are in agreement with the GFED database (NHAF, SHAF, AUST, SHSA). Seasonality also shows good agreement, whether regionally or at $1^{\circ}$ resolution (not shown). The main seasonality discrepancy occurs in sub-Saharan Africa, where the model substantially 


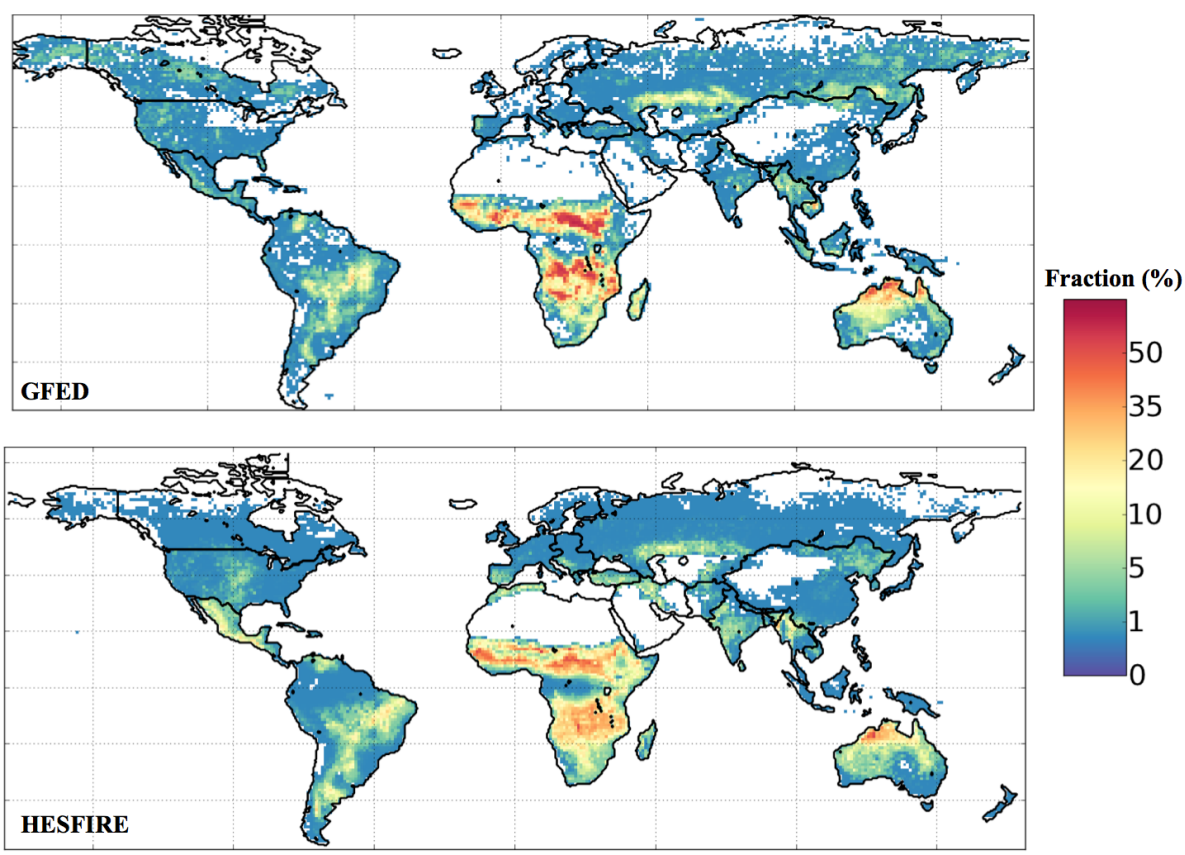

Figure 6. Observed and modeled average annual burned fraction. Top: GFEDv3 burned areas on "natural" landscapes. Bottom: fire model.

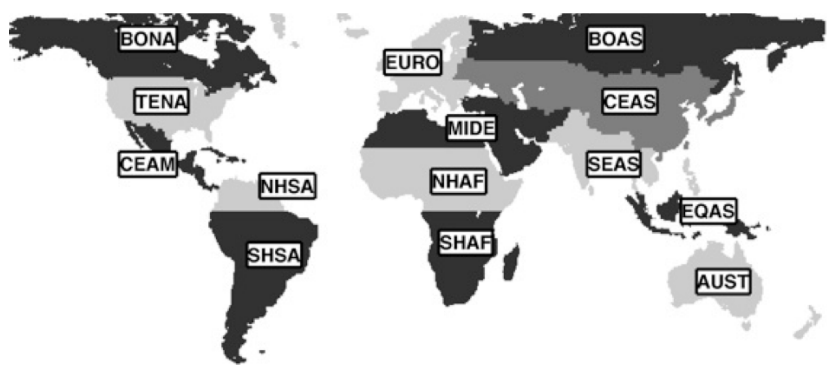

Figure 7. Regions used to aggregate observation- and modelderived fire activity data in Fig. 8.

delays the onset and peak of the fire season. Finally, HESFIRE performs unevenly regarding interannual variability, with medium to high correlation to observations in some tropical and temperate regions, but low or even negative correlation in boreal regions. It reproduces the El Niño induced anomaly in Indonesia in 1997-1998, but because of the underestimation of fire incidence mentioned before, the actual extent of that extreme fire episode is not captured.

Next to each time series, the regional fire size distribution histograms for 2005 suggest the representation of single fire size in HESFIRE is within the range of observations, and that it depicts the decreasing fire frequency as a function of fire size. It tends to overestimate the frequency of large fires and their contribution to the total burned area, however. Fire duration could not be readily evaluated with the MODIS data, but a map of maximum fire duration is provided in the Supplement to illustrate this capability (Fig. S5). $68 \%$ of the
2005 global burned area occurred in fires longer than 1 day in HESFIRE.

\subsection{Model sensitivity}

The sensitivity analysis shows the class of the parameter whose altered values $(+50$ and $-50 \%)$ led to the largest change in averaged annual burned area at the grid cell level (Fig. 9). In boreal regions, although HESFIRE does not perform well, fire incidence is mostly sensitive to weather parameters, and to a lower extent to the fuel load parameter. In humid tropical ecosystems, HESFIRE is also mostly sensitive to weather parameters, but anthropogenic parameters become dominant in areas with a substantial dry season and agricultural activities, especially in South America along the arc of deforestation. In semi-arid areas, the vegetation fuel parameter has the most influence, including in Mexico, sub-Saharan and southern sub-equatorial Africa, the horn of Africa, Australia, and Kazakhstan, with consequences for the model performance in these various regions (see discussion). Finally, HESFIRE is primarily sensitive to the landscape fragmentation parameter in several regions due to two mechanisms. In regions of high land use density (e.g., India), fire spread is constantly limited by the fragmentation parameter and fire incidence is low, but can increase (or diminish further) when altering its value. In regions of low land use density but high fire incidence due to a very seasonal climatology (e.g., sub-Saharan and northern sub-equatorial Africa), landscape fragmentation due to previous fires becomes a limiting factor for late-season fires. Finally, regions of relatively high land use density and fire incidence are probably sensitive to 


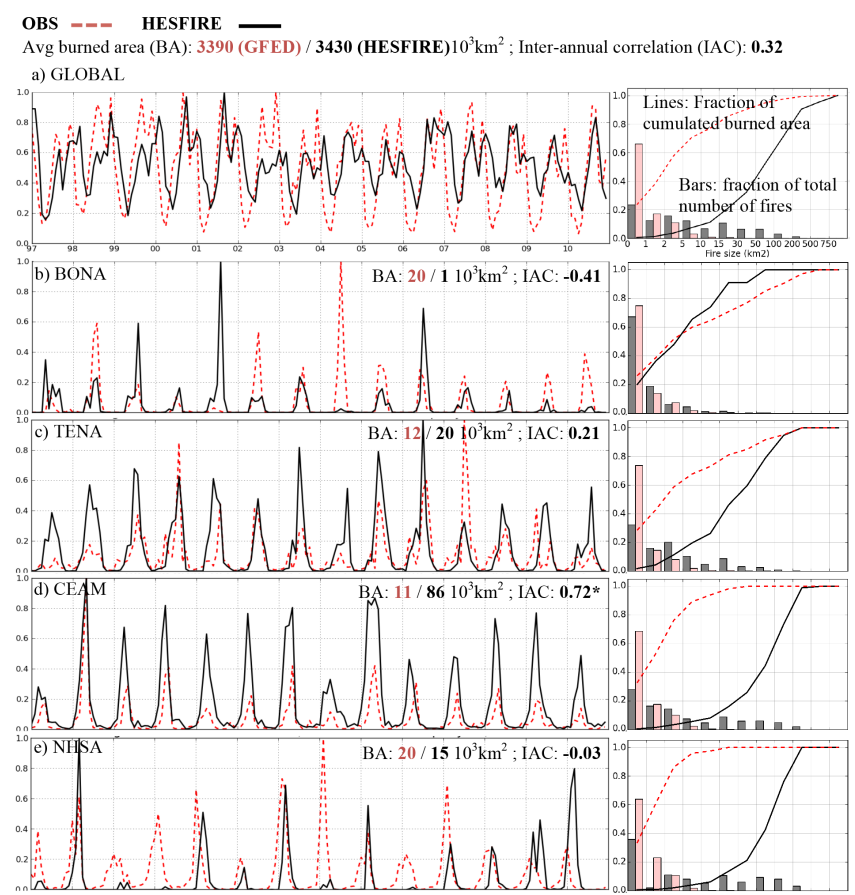

Figure 8. Comparison of HESFIRE with observation-derived data over the 14 regions of Fig. 7. Left plots: time series of normalized monthly burned area, with quantification of average annual burned area in GFED and in HESFIRE, and their interannual Spearman's correlation. Right side: 2005 distribution of fires by size class and cumulative burned area along these classes. Observation data are from the MODIS MCD45 product. An asterisk (*) indicates significance of the Spearman's correlation between the GFED and HESFIRE annual time series ( $p<0.05$, Spearman, 1904).

both mechanisms. Note that landscape fragmentation is in part due to human activities, adding to the sensitivity of the model to anthropogenic factors.

\section{Discussion}

HESFIRE shows encouraging capabilities, especially given the difficulty of achieving a good representation of global fire patterns (Bowman et al., 2011; Spessa et al., 2013). It is a first step towards the three objectives stated in the Introduction. First, the model avoids some assumptions that would be fundamentally inconsistent with fire ecology (e.g., fire spread limited to a single day). Second, it includes climatic, anthropogenic, and vegetation drivers, and the input variables were chosen so as to enable projections under altered conditions; GDP and land use are reported in future projections from integrated assessment models (Van Vuuren et al., 2011). Third, HESFIRE reproduces reasonably well many aspects of regional fire activity, including fire incidence and variability in South America and fire size, both of which were not part of the optimization procedure, and regional sensitivities to the

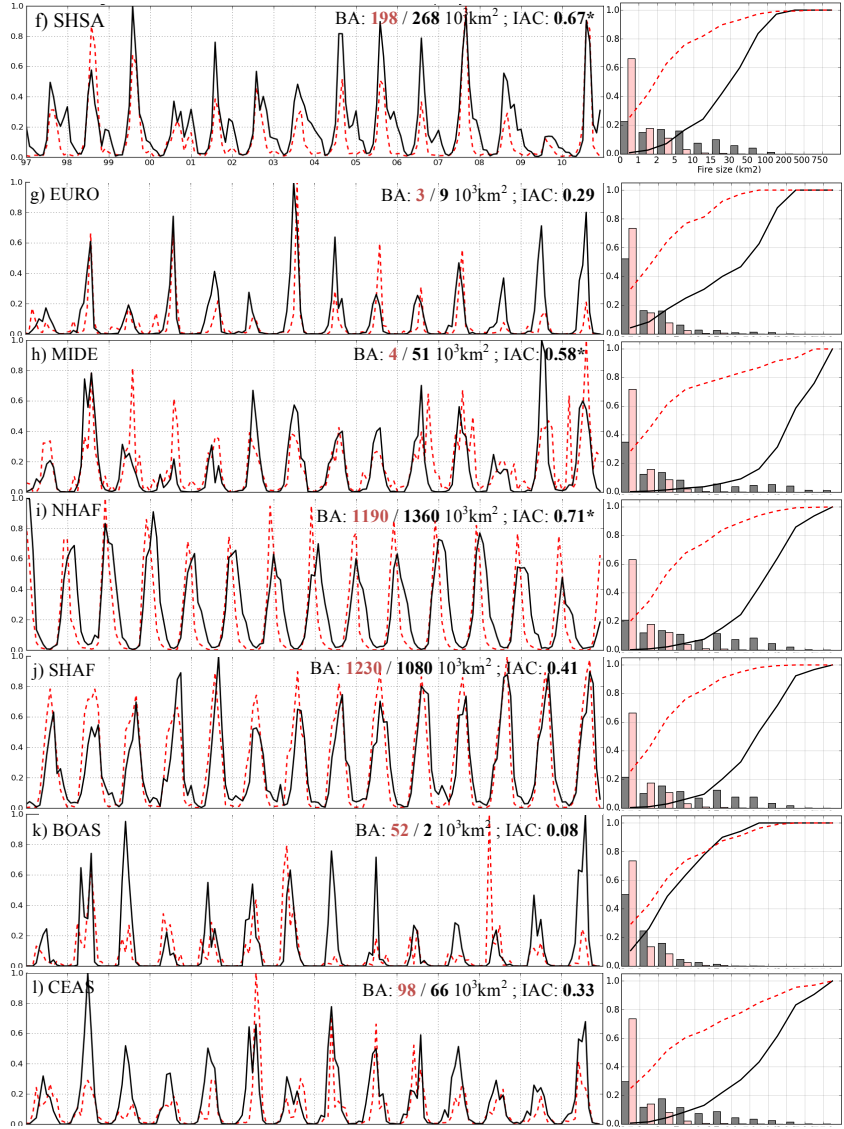

Figure 8. Continued.

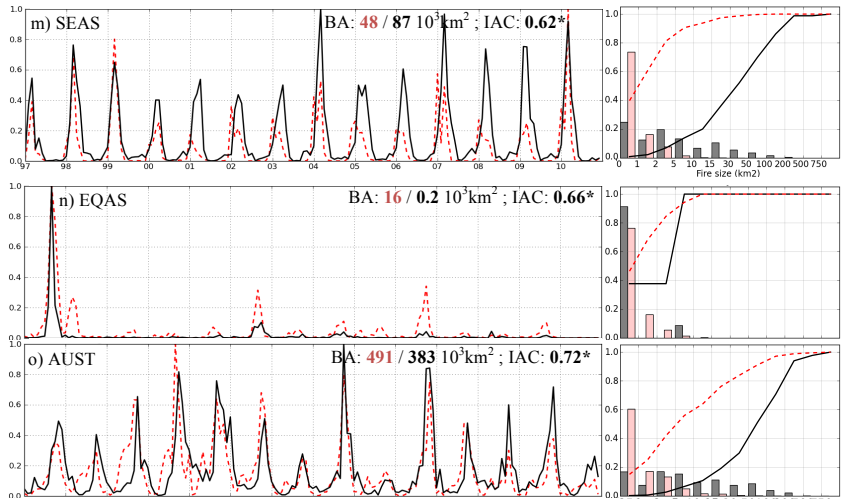

Figure 8. Continued.

four parameter classes correspond to what would be expected based on broad fire ecology concepts.

The comparison to results reported by other models - mostly fire incidence - suggests HESFIRE generally achieves strong performance with respect to spatial patterns: Fig. 6 in this paper compared to Fig. 3c in Thonicke et al. (2010, Spread and InTensity of FIRE model, SPITFIRE), Fig. 2 in Prentice et al. (2011; Land surface Processes and 


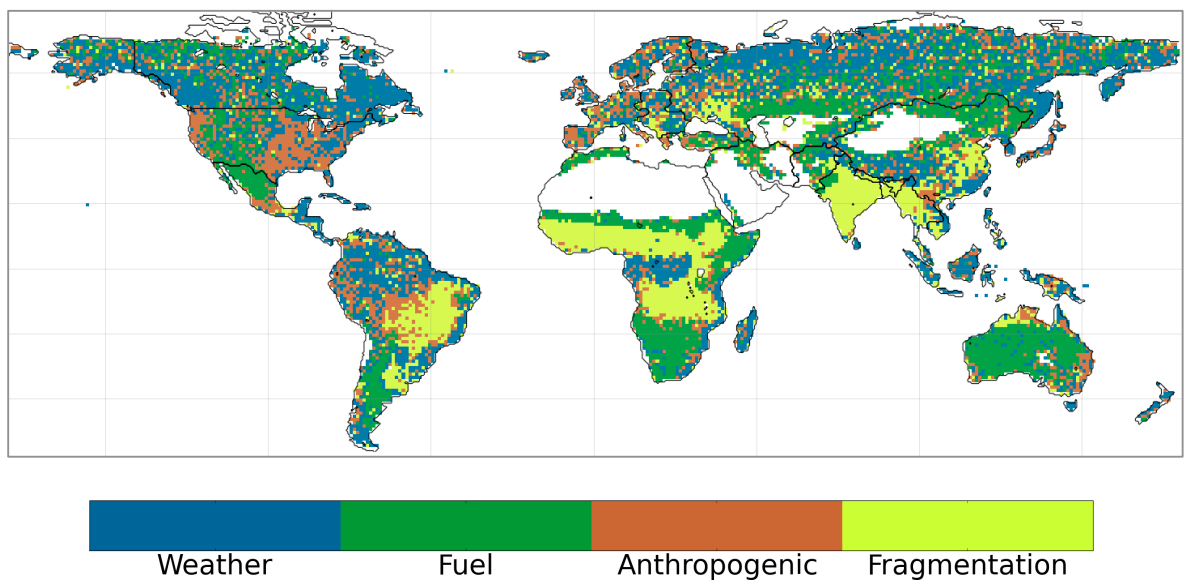

Figure 9. Major drivers of average annual burned area sensitivity among the nine optimized parameters as grouped into four thematic classes (weather, vegetation fuel, anthropogenic practices, landscape fragmentation). For each of the nine parameters, HESFIRE was run keeping the original parameterization, but altering the value of the considered parameter by -50 and $+50 \%$. The map shows the class of the parameter for which the average burned area in the considered grid cell varied the most between the two runs with these alternative values.

exchanges model, LPX), Fig. 1 in Kloster et al. (2010; Community Land Model, CLM). HESFIRE also shows strong performances with respect to the actual quantification of the average burned area fraction, with a rather infrequent occurrence of large discrepancies which are susceptible to severely biased impacts on vegetation and carbon dynamics. Note, however, that these results are not fully comparable as they are produced by fire modules embedded within dynamic vegetation models, with potential bias originating from other parts of the model (e.g., land cover distribution, fuel load). The fire model developed by Li et al. (2012) in the Community Land Model's Dynamic Global Vegetation Model (CLM-DGVM) and modified to better account for anthropogenic ignitions has spatial patterns of averaged burned area similar to HESFIRE (Fig. 9 in Li et al., 2013).

\subsection{Fires in semi-arid regions and links to the fuel proxy}

The combination of these characteristics and performance suggests that the modeling and optimization framework realistically captures the primary fire-driving mechanisms and the specific magnitude of their influence regionally. It could thus bring relevant insights into future fire activity under altered environmental conditions, including agricultural expansion and extreme climate events (e.g., sustained droughts). There are however a number of issues, as well as key potential improvements which we discuss in the next sections.

\subsection{Fire incidence in boreal regions}

HESFIRE underestimates fire incidence in Boreal regions. This issue has been reported before in another fire model (Rupp et al., 2007), which projected almost no burned area when driven by the NCEP data but performed better when driven by other data sets. Serreze and Hurst (2000) found that summer precipitation is largely overestimated in NCEP, compromising the whole hydrological cycle including $\mathrm{RH}$ and soil moisture. Alternative data sets may address this issue, either by using them as direct input or for correcting the bias in the NCEP data while maintaining its high temporal resolution and extensive timespan.

HESFIRE might be further limited because it does not represent specific aspects of boreal fire regimes. In particular, boreal needleleaf forests are highly flammable and have a vertical structure favorable to the development of crown fires, which spread faster and can overcome higher levels of moisture and humidity (Ryan, 2002). Additionally, large boreal fires typically spread over weeks or months - which can be captured by HESFIRE - but might also remain dormant in a smoldering phase during fire-averse conditions and reactivate later without any new ignitions (Sedano and Randerson, 2014).

Semi-arid ecosystems presented a particular challenge due to the sensitivity of fuel characteristics to soil, precipitation, and potential evapotranspiration conditions, which cannot be fully captured by the cumulative precipitation proxy. In the final parameterization, HESFIRE is in good agreement with observations in Australia, southern hemispheric Africa, and Kazakhstan, but overestimates fire incidence in Mexico, the horn of Africa, and semi-desert areas at the border of the Sahara (Fig. 8). Precipitation patterns in these xeric landscapes vary widely. Some semi-desert regions have low amounts of precipitation year-round (Kazakhstan), while others have short rainy seasons (sub-Saharan Africa). The optimization procedure favors one set of conditions, leading to unequal performances across these regions. 
Clearly there are other potential factors contributing to this issue. The integration of HESFIRE within a vegetation model could provide dynamic and process-based estimates of fuel load, fuel structure, and fuel moisture. In parallel, integrating observation-derived estimates of aboveground biomass (Saatchi et al., 2011) as a fuel-proxy could improve performances while maintaining the value of a stand-alone version of HESFIRE. Finally, semi-arid regions generally feature strong precipitation gradients which influence the spatial distribution of vegetation and fuel load, and are not captured accurately by the raw input data $\left(2.5^{\circ}\right)$ or through their interpolation to $1^{\circ}$.

\subsection{Representation of anthropogenic ignitions}

Modeling the global diversity of fire practices remains a significant challenge. HESFIRE performs well in regions with a well-established anthropogenic footprint of fire regimes, even though it is based on a simplistic representation of fire practices and suppression effort by necessity of obtaining a globally consistent initial approach. The timing and frequency of anthropogenic ignitions are complex phenomena to represent in global models. In sub-Saharan Africa for example, local populations are known to burn numerous small fires early in the dry season to fragment the landscape and limit the occurrence of high-intensity late-season fires (Laris, 2002; Le Page et al., 2010a). These fire management practices are not accounted for in HESFIRE, leading to a delayed fire-peak month (by 1-3 months), and to an overestimation of the average fire size. Beyond this specific case, fire practices vary as a function of land use (e.g., agriculture, pastures), of land use transitions (e.g., deforestation and postclearing activities, Morton et al., 2008), of land management practices (fire prevention, fire suppression), and can also be due to arson or leisure activities (e.g., campfire). For agricultural lands, fire practices are very specific (clearing, presowing, pre- and post-harvest burns) and last for as little as a week to several months (Le Page et al., 2010a). Finally, these practices vary at local to global scale according to environmental conditions, the availability of alternatives to fires (e.g., fertilizer, pest control), national regulations, fire fighting capabilities, etc. There is not much ground to believe fire practices will closely follow future GDP and land use trends, but these factors are part of the equation. Research towards a better representation of broad classes of fire practices is ongoing (Li et al., 2013), and, as mentioned in other studies, fire driver analysis over longer periods (e.g., with historical reconstruction, Mouillot and Field, 2005) would provide further guidance.

\subsection{Representation of fire spread}

The evaluation suggests the modeled average fire size is within the observed range, but HESFIRE tends to overestimate the contribution of large fires, which could be linked to the representation of fire spread as an idealized elliptical shape, similar to other global fire models. Burned areas are typically patchy and the front line rarely remains unbroken around the perimeter of the fire, especially in fragmented and uneven landscapes. Better accounting for these aspects could improve models performances, for example with the implementation of a fragmentation feedback on the fraction of the idealized elliptical shape that actually burns.

Additionally, anthropogenic fire practices mentioned in Sect. 4.3 can have a substantial footprint on fire size, including in regions where it is overestimated by HESFIRE. In subSaharan Africa for example, a better representation of small early dry-season burns as a fire management practice would lead to a more realistic accounting of fire sizes and of the landscape fragmentation feedback on late-season fire spread.

\section{Conclusions}

This analysis highlights the strengths of the HESFIRE model as well as its limitations and opportunities to address them. The representation of multi-day fires opens the perspective to explore regional sensitivities of fire duration to climate change (e.g., longer droughts). The calibration of the anthropogenic ignition function - suggesting a very rapid saturation of ignitions with land use density - can be applied to gridded land use scenarios to explore potential implications of terrestrial policies for fire activity. Ultimately, however, exploring interactions between fires, the terrestrial biosphere, and the atmosphere relies on frameworks of the coupled humanEarth system. The data-assimilation methods applied here to infer fire-driving parameters may provide additional guidance for the parameterization of such complex models. The integration of HESFIRE into a dynamic global vegetation model (DGVM) could also provide insights into the contribution of fire-driving assumptions, observation data, and DGVM-derived vegetation/fuel characteristics to model performances.

\section{The Supplement related to this article is available online at doi:10.5194/bg-12-887-2015-supplement.}

Author contributions. Y. Le Page developed the model and performed the simulations, Y. Le Page, B. Bond-Lamberty, and G. Hurt designed the optimization procedure, and Y. Le Page prepared the manuscript with contribution from all authors.

Acknowledgements. The authors are grateful for research support provided by the NASA Terrestrial Ecology and Inter-Disciplinary Studies programs. The authors also wish to express appreciation to the Integrated Assessment Research Program in the Office of 
Science of the U.S. Department of Energy for partially funding this research. The Pacific Northwest National Laboratory is operated for DOE by Battelle Memorial Institute under contract DE-AC05-76RL01830. The views and opinions expressed in this paper are those of the authors alone.

Edited by: S. Zaehle

\section{References}

Abatzoglou, J. T. and Kolden, C. A.: Relative importance of weather and climate on wildfire growth in interior Alaska, Int. J. Wildland Fire, 20, 479-486, 2011.

Adler, R. F., Huffman, G. J., Chang, A., Ferraro, R., Xie, P. P., Janowiak, J., Rudolf, B., Schneider, U., Curtis, S., and Bolvin, D.: The version-2 global precipitation climatology project (GPCP) monthly precipitation analysis (1979-present), J. Hydrometeorol., 4, 1147-1167, 2003.

Allen, D. J. and Pickering, K. E.: Evaluation of lightning flash rate parameterizations for use in a global chemical transport model, J. Geophys. Res.-Atmos., (1984-2012), 107, ACH-15, 2002.

Arora, V. K. and Boer, G. J.: Fire as an interactive component of dynamic vegetation models, J. Geophys. Res.-Biogeo., 110, 20052012, 2005.

Bontemps, S., Defourny, P., Bogaert, E. V., Arino, O., Kalogirou, V., and Perez, J. R.: GLOBCOVER 2009-Products Description and Validation Report, available at: http://www.citeulike.org/group/ 15400/article/12770349 (last access: 25 February 2014), 2011.

Bowman, D. M. J. S., Balch, J. K., Artaxo, P., Bond, W. J., Carlson, J. M., Cochrane, M. A., D’Antonio, C. M., DeFries, R. S., Doyle, J. C., Harrison, S. P., Johnston, F. H., Keeley, J. E., Krawchuk, M. A., Kull, C. A., Marston, J. B., Moritz, M. A., Prentice, I. C., Roos, C. I., Scott, A. C., Swetnam, T. W., Werf, G. R. van der, and Pyne, S. J.: Fire in the Earth System, Science, 324, 481-484, doi:10.1126/science.1163886, 2009.

Bowman, D. M. J. S., Balch, J., Artaxo, P., Bond, W. J., Cochrane, M. A., D'Antonio, C. M., DeFries, R., Johnston, F. H., Keeley, J. E., Krawchuk, M. A., Kull, C. A., Mack, M., Moritz, M. A., Pyne, S., Roos, C. I., Scott, A. C., Sodhi, N. S., and Swetnam, T. W.: The human dimension of fire regimes on Earth, J. Biogeogr., 38, 2223-2236, doi:10.1111/j.1365-2699.2011.02595.x, 2011.

Christian, H. J., Blakeslee, R. J., Boccippio, D. J., Boeck, W. L., Buechler, D. E., Driscoll, K. T., Goodman, S. J., Hall, J. M., Koshak, W. J., Mach, D. M., and Stewart, M.F. : Global frequency and distribution of lightning as observed from space by the Optical Transient Detector, J. Geophys. Res.-Atmos., (19842012), 108, ACL-4, 2003.

CIA: The world factbook 2009, Central Intelligence Agency, Washington, DC, available at: https://www.cia.gov/library/ publications/download/download-2009 (last access: 9 February 2015), 2009.

Giglio, L., Randerson, J. T., van der Werf, G. R., Kasibhatla, P. S., Collatz, G. J., Morton, D. C., and DeFries, R. S.: Assessing variability and long-term trends in burned area by merging multiple satellite fire products, Biogeosciences, 7, 1171-1186, doi:10.5194/bg-7-1171-2010, 2010.

Giglio, L., Randerson, J. T., and van der Werf, G. R.: Analysis of daily, monthly, and annual burned area using the fourth- generation global fire emissions database (GFED4): Analysis of burned area, J. Geophys. Res.-Biogeo., 118, 317-328, doi:10.1002/jgrg.20042, 2013.

Greenville, A. C., Dickman, C. R., Wardle, G. M., and Letnic, M.: The fire history of an arid grassland: the influence of antecedent rainfall and ENSO, Int. J. Wildland Fire, 18, 631-639, 2009.

Jaeger, J. A.: Landscape division, splitting index, and effective mesh size: new measures of landscape fragmentation, Landscape Ecol., 15, 115-130, 2000.

Kanamitsu, M., Ebisuzaki, W., Woollen, J., Yang, S. K., Hnilo, J. J., Fiorino, M., and Potter, G. L.: Ncep-doe amip-ii reanalysis (r-2), B. Am. Meteorol. Soc., 83, 1631-1644, 2002.

Kloster, S., Mahowald, N. M., Randerson, J. T., Thornton, P. E., Hoffman, F. M., Levis, S., Lawrence, P. J., Feddema, J. J., Oleson, K. W., and Lawrence, D. M.: Fire dynamics during the 20th century simulated by the Community Land Model, Biogeosciences, 7, 1877-1902, doi:10.5194/bg-7-1877-2010, 2010.

Korontzi, S., McCarty, J., Loboda, T., Kumar, S., and Justice, C.: Global distribution of agricultural fires in croplands from 3 years of Moderate Resolution Imaging Spectroradiometer (MODIS) data, Global Biogeochem. Cy., 20, GB2021, doi10.1029/2005GB002529, 2006.

Laris, P.: Burning the seasonal mosaic: preventative burning strategies in the wooded savanna of southern Mali, Hum. Ecol., 30, 155-186, 2002.

Le Page, Y., Pereira, J. M. C., Trigo, R., da Camara, C., Oom, D., and Mota, B.: Global fire activity patterns (1996-2006) and climatic influence: an analysis using the World Fire Atlas, Atmos. Chem. Phys., 8, 1911-1924, doi:10.5194/acp-8-1911-2008, 2008.

Le Page, Y., Oom, D., Silva, J., Jönsson, P., and Pereira, J.: Seasonality of vegetation fires as modified by human action: observing the deviation from eco-climatic fire regimes, Global Ecol. Biogeogr., 19, 575-588, 2010a.

Le Page, Y., van der Werf, G., Morton, D., and Pereira, J.: Modeling fire-driven deforestation potential in Amazonia under current and projected climate conditions, J. Geophys. Res., 115, G03012, doi:10.1029/2009JG001190, 2010b.

Li, F., Zeng, X. D., and Levis, S.: A process-based fire parameterization of intermediate complexity in a Dynamic Global Vegetation Model, Biogeosciences, 9, 2761-2780, doi:10.5194/bg-9-27612012, 2012.

Li, F., Levis, S., and Ward, D. S.: Quantifying the role of fire in the Earth system - Part 1: Improved global fire modeling in the Community Earth System Model (CESM1), Biogeosciences, 10, 2293-2314, doi:10.5194/bg-10-2293-2013, 2013.

Metropolis, N., Rosenbluth, A. W., Rosenbluth, M. N., Teller, A. H., and Teller, E.: Equation of state calculations by fast computing machines, The journal of chemical physics, 21, 1087-1092, 1953.

Morton, D. C., Defries, R. S., Randerson, J. T., Giglio, L., Schroeder, W., and van Der Werf, G. R.: Agricultural intensification increases deforestation fire activity in Amazonia, Glob. Change Biol., 14, 2262-2275, 2008.

Morton, D. C., Le Page, Y., DeFries, R., Collatz, G. J., and Hurtt, G. C.: Understorey fire frequency and the fate of burned forests in southern Amazonia, Philos. T. R. Soc. B, 368, doi:10.1098/rstb.2012.0163, 2013. 
Mouillot, F. and Field, C. B.: Fire history and the global carbon budget: a $1^{\circ} \times 1^{\circ}$ fire history reconstruction for the 20th century, Glob. Change Biol., 11, 398-420, doi:10.1111/j.13652486.2005.00920.x, 2005.

Mouillot, F., Schultz, M. G., Yue, C., Cadule, P., Tansey, K., Ciais, P., and Chuvieco, E.: Ten years of global burned area products from spaceborne remote sensing - A review: Analysis of user needs and recommendations for future developments, Int. J. Appl. Earth Obs., 26, 64-79, doi:10.1016/j.jag.2013.05.014, 2014.

Page, S. E., Siegert, F., Rieley, J. O., Boehm, H.-D. V., Jaya, A., and Limin, S.: The amount of carbon released from peat and forest fires in Indonesia during 1997, Nature, 420, 61-65, 2002.

Parry, M. L.: Climate Change 2007: Impacts, Adaptation and Vulnerability: Working Group II Contribution to the Fourth Assessment Report of the IPCC Intergovernmental Panel on Climate Change, Cambridge University Press, 976 pp., 2007.

Pechony, O. and Shindell, D. T.: Fire parameterization on a global scale, J. Geophys. Res.-Atmos. (1984-2012), 114, D16115, doi:10.1029/2009JD011927, 2009.

Pereira, M. G., Trigo, R. M., da Camara, C. C., Pereira, J. M. C., and Leite, S. M.: Synoptic patterns associated with large summer forest fires in Portugal, Agr. Forest Meteorol., 129, 11-25, doi:10.1016/j.agrformet.2004.12.007, 2005.

Pfeiffer, M., Spessa, A., and Kaplan, J. O.: A model for global biomass burning in preindustrial time: LPJ-LMfire (v1.0), Geosci. Model Dev., 6, 643-685, doi:10.5194/gmd-6-643-2013, 2013.

Podur, J., Martell, D. L., and Csillag, F.: Spatial patterns of lightning-caused forest fires in Ontario, 1976-1998, Ecol. Model., 164, 1-20, doi:10.1016/S0304-3800(02)00386-1, 2003.

Potter, C. S., Wang, S., Nikolov, N. T., McGuire, A. D., Liu, J., King, A. W., Kimball, J. S., Grant, R. F., Frolking, S. E., Clein, J. S., Chen, J. M., and Amthor, J. S.: Comparison of boreal ecosystem model sensitivity to variability in climate and forest site parameters, J. Geophys. Res., 106, 33671-33687, doi:10.1029/2000JD000224, 2001.

Prentice, I. C., Kelley, D. I., Foster, P. N., Friedlingstein, P., Harrison, S. P., and Bartlein, P. J.: Modeling fire and the terrestrial carbon balance, Global Biogeochem. Cy., 25, GB3005, doi:10.1029/2010GB003906, 2011.

Prentice, S. A. and Mackerras, D.: The ratio of cloud to cloudground lightning flashes in thunderstorms, J. Appl. Meteorol., 16, 545-550, 1977.

Rothermel, R. C. and Forest, I.: A mathematical model for predicting fire spread in wildland fuels, available at: http://www.snap.uaf.edu/webshared/JenNorthway/ AKFireModelingWorkshop/AKFireModelingWkshp/ FSProAnalysisGuideReferences/Rothermel1972INT-115.pdf (last access: 18 September 2014), 1972.

Roy, D. P., Boschetti, L., Justice, C. O., and Ju, J.: The collection 5 MODIS burned area product-Global evaluation by comparison with the MODIS active fire product, Remote Sens. Environ., 112, 3690-3707, 2008.

Rupp, T. S., Xi Chen, Olson, M., and McGuire, A. D.: Sensitivity of Simulated Boreal Fire Dynamics to Uncertainties in Climate Drivers, Earth Interact., 11, 1-21, 2007.

Ryan, K. C.: Dynamic interactions between forest structure and fire behavior in boreal ecosystems, Silva Fenn., 36, 13-39, 2002.
Saatchi, S. S., Harris, N. L., Brown, S., Lefsky, M., Mitchard, E. T. A., Salas, W., Zutta, B. R., Buermann, W., Lewis, S. L., Hagen, S., Petrova, S., White, L., Silman, M., and Morel, A.: Benchmark map of forest carbon stocks in tropical regions across three continents, PNAS, 108, 9899-9904, doi:10.1073/pnas.1019576108, 2011.

Saltelli, A., Tarantola, S., and Campolongo, F.: Sensitivity Analysis as an Ingredient of Modeling, Stat. Sci., 15, 377-395, 2000.

Schumaker, N. H.: Using landscape indices to predict habitat connectivity, Ecology, 77, 1210-1225, 1996.

Scott, J. H. and Burgan, R. E.: Standard fire behavior fuel models: a comprehensive set for use with Rothermel's surface fire spread model, The Bark Beetles, Fuels, and Fire Bibliography, 66, 81 pp., 2005.

Sedano, F. and Randerson, J. T.: Vapor pressure deficit controls on fire ignition and fire spread in boreal forest ecosystems, Biogeosciences Discuss., 11, 1309-1353, doi:10.5194/bgd-11-13092014, 2014.

Serreze, M. C. and Hurst, C. M.: Representation of Mean Arctic Precipitation from NCEP-NCAR and ERA Reanalyses., J. Climate, 13, 182-201, 2000.

Spearman, C.: The proof and measurement of association between two things, The American journal of psychology, 15, 72-101, 1904.

Spessa, A., van der Werf, G., Thonicke, K., Gomez Dans, J., Lehsten, V., Fisher, R., and Forrest, M.: Modeling vegetation fires and fire emissions, in Vegetation Fires and Global Change - Challenges for Concerted International Action, A White Paper directed to the United Nations and International Organizations, edited by: Goldammer, J. G., 181-207, Kessel, available at: http://www.forestrybooks.com (last access: 19 September 2014), 2013.

Stocker, T. F., Dahe, Q., and Plattner, G.-K.: Climate Change 2013: The Physical Science Basis, Working Group I Contribution to the Fifth Assessment Report of the Intergovernmental Panel on Climate Change, Summary for Policymakers (IPCC, 2013), available at: http://www.climatechange2013.org/images/report/ WG1AR5_Frontmatter_FINAL.pdf (last access: 28 February 2014), 2013.

Stocks, B. J., Mason, J. A., Todd, J. B., Bosch, E. M., Wotton, B. M., Amiro, B. D., Flannigan, M. D., Hirsch, K. G., Logan, K. A., Martell, D. L., and Skinner, W. R.: Large forest fires in Canada, 1959-1997, J. Geophys. Res., 107, 8149, doi:10.1029/2001JD000484, 2002.

Thonicke, K., Venevsky, S., Sitch, S., and Cramer, W.: The Role of Fire Disturbance for Global Vegetation Dynamics: Coupling Fire into a Dynamic Global Vegetation Model, Global Ecol. Biogeogr., 10, 661-677, doi:10.1046/j.1466-822X.2001.00175.x, 2001.

Thonicke, K., Spessa, A., Prentice, I. C., Harrison, S. P., Dong, L., and Carmona-Moreno, C.: The influence of vegetation, fire spread and fire behaviour on biomass burning and trace gas emissions: results from a process-based model, Biogeosciences, 7 , 1991-2011, doi:10.5194/bg-7-1991-2010, 2010.

Thrupp, L. A., Hecht, S., Browder, J. O., and Institute, W. R.: The diversity and dynamics of shifting cultivation: myths, realities, and policy implications, World Resources Institute, 53 pp., 1997.

van der Werf, G. R., Dempewolf, J., Trigg, S. N., Randerson, J. T., Kasibhatla, P. S., Giglio, L., Murdiyarso, D., Peters, W., Morton, 
D. C., and Collatz, G. J.: Climate regulation of fire emissions and deforestation in equatorial Asia, P. Natl. Acad. Sci., 105, 2035020355, 2008.

Van Vuuren, D. P., Edmonds, J., Kainuma, M., Riahi, K., Thomson, A., Hibbard, K., Hurtt, G. C., Kram, T., Krey, V., and Lamarque, J.-F.: The representative concentration pathways: an overview, Clim. Change, 109, 5-31, 2011.

van der Werf, G. R., Randerson, J. T., Giglio, L., Collatz, G. J., Mu, M., Kasibhatla, P. S., Morton, D. C., DeFries, R. S., Jin, Y., and van Leeuwen, T. T.: Global fire emissions and the contribution of deforestation, savanna, forest, agricultural, and peat fires (19972009), Atmos. Chem. Phys., 10, 11707-11735, doi:10.5194/acp10-11707-2010, 2010.

Van Wilgen, B. w., Govender, N., Biggs, H. c., Ntsala, D. and Funda, X. n.: Response of Savanna Fire Regimes to Changing Fire-Management Policies in a Large African National Park, Conserv. Biol., 18, 1533-1540, doi:10.1111/j.15231739.2004.00362.x, 2004.
Westerling, A. L., Cayan, D. R., Brown, T. J., Hall, B. L., and Riddle, L. G.: Climate, Santa Ana winds and autumn wildfires in southern California, Eos, T. Am. Geophys. Un., 85, 289-296, 2004.

White, M. A., Thornton, P. E., Running, S. W., and Nemani, R. R.: Parameterization and Sensitivity Analysis of the BIOME-BGC Terrestrial Ecosystem Model: Net Primary Production Controls, Earth Interact., 4, 1-85, doi:10.1175/10873562(2000)004<0003:PASAOT>2.0.CO;2, 2000.

Zaehle, S. and Friend, A. D.: Carbon and nitrogen cycle dynamics in the O-CN land surface model: 1. Model description, site-scale evaluation, and sensitivity to parameter estimates, Global Biogeochem. Cy., 24, GB1005, doi:10.1029/2009GB003521, 2010. 